\title{
Oral health status and trace elements in saliva of children and teenagers with intellectual disabilities: A preliminary study
}

\author{
Ruiz Roca Juna Antonio ${ }^{1}$, Lorca Larrosa Maria ${ }^{1}$, Ruiz Roca MI ${ }^{2}$, Tvarijonaviciute Asta ${ }^{3}$, Pons-Fuster Eduardo ${ }^{1}$ and López- Jornet Pia ${ }^{4 *}$ \\ ${ }^{1}$ Department of Medicine and Dentistry, University of Murcia, Spain \\ ${ }^{2}$ Head of studies at Public Special Education Center (c.p.e.e. primitiva lópez), Cartagena, Spain \\ ${ }^{3}$ Regional campus of international excellence "mare nostrum”, university of Murcia, ed.16, 4a planta, Espinardo, Murcia, Spain \\ ${ }^{4}$ Oral Medicine, Faculty of Medicine and Dentistry, University of Murcia, Spain
}

\begin{abstract}
Aim: The aim of this study was to assess oral health status and analyze trace elements present in the saliva of children with intellectual disabilities and compare them with a control group.

Methods: This prospective case-control study included 30 patients diagnosed with intellectual disability attending the Primitiva López Special Education Center (Cartagena, Spain) and 22 healthy control subjects. Medical histories were prepared for each subject who then underwent oral examination. Unstimulated whole saliva was collected and the following elements were measured using inductively coupled plasma mass spectrometry (ICP-MS): Ca, Cr, $\mathrm{Cu}, \mathrm{Fe}, \mathrm{K}, \mathrm{Mg}$, $\mathrm{Mn}, \mathrm{Na}, \mathrm{Ni}$, $\mathrm{Pb}, \mathrm{P}, \mathrm{Rb}, \mathrm{S}$ and $\mathrm{Zn}$.
\end{abstract}

Results: The oral and dental health status of patients with intellectual disability was similar to that of control group subjects. Similar values were found in both the study group and the control group for $\mathrm{Ca}, \mathrm{K}, \mathrm{Mg}, \mathrm{Na}, \mathrm{Pb}, \mathrm{P}$ and $\mathrm{S}$. Significantly higher values were found in the study group for Fe and $\mathrm{Mn}$ ( $\mathrm{p}<0.01$ ).

Conclusion: The present finding that Fe and Mn are present at higher levels in the saliva of study group patients poses the question of whether these differences could be a reflection of intellectual disability.

\section{Clinical significance}

Trace elements or oligoelements play a vital role in maintaining the integrity of a range of physiological and metabolic processes. In this context determining the concentrations of trace elements is important for a better understanding of their impact on oral health.

\section{Introduction}

Oral health is an important component of general health and promoting oral health can reduce the overall burden of illness. Patients with intellectual disability are often a forgotten group when it comes to oral healthcare although they may require complex multidisciplinary care [1-3]. The evidence shows that persons with intellectual disability suffer worse oral health, periodontal status, and present a higher risk of caries [1-3]. In addition to compromised oral health status, these patients may also have greater difficulty in accessing oral healthcare services [1-6]. Routine oral healthcare and dental treatment is often erratic, leading to poor oral health and the rapid progression of any oral diseases present $[2,7]$.

Trace elements or oligoelements play a vital role in maintaining the integrity of a range of physiological and metabolic processes that take place in living tissue. As each trace element is related to enzymatic systems, the inadequate ingress of trace elements into the organism may have deleterious effects on different tissue functions and may lead to disease [8]. For this reason, analyzing changes to the concentrations of oligoelements in saliva could lead to better understanding of any oral functional abnormalities present [9-10].

Hedge, et al. [11] found significant increases in $\mathrm{Cu}$ and $\mathrm{Zn}$ in the saliva of patients with caries in comparison with a caries-free control group. Watanabe, et al. [12] also reported an increase in salival $\mathrm{Cu}$ among subjects with caries. But these findings contradict Borella, et al. [13] who reported reductions in $\mathrm{Zn}$ and $\mathrm{Cu}$ proportions in patients with more than three carious teeth. Gaur and Agnihotri [14] found that micronutrient oligoelements such as $\mathrm{Fe}, \mathrm{Zn}, \mathrm{Cu}$ and Se are essential for regulating immuno-inflammatory pathways and increased levels can be a reflection of chronic periodontitis. In this way, identifying and measuring biomarkers can help assess oral health status and it is for this reason many researchers have set out to identify the specific markers of each oral disease $[15,16]$.

${ }^{\star}$ Correspondence to: López- Jornet Pia, senior lecturer and professor of oral medicine, faculty of medicine and dentistry, university of murcia. Hospital morales meseguer. clínica odontológica universitaria. Medicina oral adv. Marques de los velez s/n murcia 30008. Spain, Tel: 0034968 398588; E-mail: majornet@um.es

Received: December 02, 2019; Accepted: December 12, 2019; Published: December 16, 2019 
The aim of this study was to analyze the oral health status and presence of trace elements in children with intellectual disability, comparing data with a control group.

\section{Materials and methods}

\section{Design, area, study population, and ethical considerations}

This prospective, observational case-control study was designed to fulfill regulations established in the Helsinki Declaration and was approved by the Research Ethics Committee of the University of Murcia (16 $6^{\text {th }}$ October 2014). Informed consent was obtained from the parents/guardians of the subjects. The study followed the STROBE (Strengthening the Reporting of Observational Studies in Epidemiology) guidelines

The study group was made up of children attending a state-run Special Education Center (CPEE Primitiva López, Cartagena, Murcia, Spain). The center has 143 students aged between 4 and 21 years with different levels of intellectual disability (slight, moderate, or severe). A total of 30 subjects were recruited into the study participants are consecutively selected in order of apperance according to their convenient accessibility. All underwent oral examination and saliva sampling. The control group consisted of children without any disability (between 7years and -15 years age group) attending the Santa María de la Paz primary school in Murcia (Spain), matched to the study group

\section{Inclusion, and exclusion criteria}

Study group inclusion criteria were: subjects with intellectual disability defined according to WHO criteria. Exclusion criteria were: the presence of dental restorations, prostheses, orthodontic apparatus, or treatment by anticolinergics, acute infection, decompensated systemic disease, cancer, radiotherapy, or unwillingness to grant consent to take part. Medical notes were prepared for each subject registering socio-demographic information and the data obtained in oral examination. A single researcher (MLL) performed all intraoral examinations of subjects in both groups, registering the following: presence of caries (according to criteria proposed by the WHO in Oral Health Survey Basic Methods); the presence or absence of oral mucosa lesions, soft and hard deposits evaluated using the simplified Greene and Vermillion oral hygiene index (OHI-S).

\section{Saliva collection}

Unstimulated mixed saliva was collected in repose using the draining method, always in the morning. The patient was instructed not to eat or chew gum for 2 hours before collection. Patients remained seated in a comfortable position with the head slightly inclined forwards and the lips half open. They were asked to hold the saliva collecting in the mouth for a minute, allowing it to fall into a funnel placed in a calibrated test tube at the end of each minute; the process was continued for 5 minutes.

Trace element analysis was performed at the Science and Applied Biology Center (CEBAS-CSIC) of the University of Murcia (Spain). Inductively coupled plasma mass spectrometry (ICP-MS) was used to analyze levels in saliva of $\mathrm{Ca}, \mathrm{Cr}, \mathrm{Cu}, \mathrm{Fe}, \mathrm{K}, \mathrm{Mg}, \mathrm{Mn}, \mathrm{Na}, \mathrm{Ni}, \mathrm{Pb}, \mathrm{P}, \mathrm{Rb}$, $\mathrm{S}$ and $\mathrm{Zn}$.

\section{Statistical analysis}

Statistical analysis was carried out using IBM SPSS Statistics v21 software (SPSS Inc., Chicago, IL, USA). Homogeneity of variance was analyzed using Levene's test. Comparison of means was performed applying Student's t-test for independent samples for two factors. Statistical significance was set at $\mathrm{p}<0.05$.

\section{Results}

The general characteristics of the study population are shown in Table 1. A relatively low percentage (13.3\%) of the study group presented slight intellectual disability. With regard to medication, subjects were taking a mean of $1.20 \pm 1.15$ drugs. Of all patients with disability, $66.7 \%$ did not speak or had problems communicating; only $33.3 \%$ were able to communicate without difficulty. Oral exploration found that of the 30 subjects in the study group, 11 (36.7\%) presented caries. Only one presented an oral lesion (queilitis exfoliative).

When soft deposits on teeth were examined, no significant differences were found between the study and control groups ( $p>0.05)$. But for hard deposits on dental surfaces, significant differences were found $(\mathrm{p}<0.01)$ between the groups, hard deposits having greater presence in the control group. In the analysis of trace elements present in saliva, similar values were found between the study and control groups for $\mathrm{Ca}, \mathrm{K}, \mathrm{Mg}, \mathrm{Na}, \mathrm{Pb}, \mathrm{P}$ y $\mathrm{S}$. In the study group values for $\mathrm{Cr}$, $\mathrm{Cu}, \mathrm{Fe}, \mathrm{Mn}, \mathrm{Ni}, \mathrm{Rb}$ and $\mathrm{Zn}$ were higher, although statistically significant differences were only identified for Fe and $\mathrm{Mn}(\mathrm{p}<0.01)$ (Table 2).

Table 1. The general characteristics of the study population

\begin{tabular}{|c|c|c|c|c|}
\hline & & $\begin{array}{l}\text { Disability } \\
(\mathrm{n}=\mathbf{3 0})\end{array}$ & $\begin{array}{l}\text { Control group } \\
(n=22)\end{array}$ & P-value \\
\hline Age years & & $15.03 \pm 4.61$ & $12 \pm 0.5$ & $<0.05$ \\
\hline \multirow[t]{2}{*}{ Sex } & Male: n (\%) & $20(66.7 \%)$ & $13(59.1 \%)$ & 0.575 \\
\hline & Female: n (\%) & $10(33.3 \%)$ & $9(40.9 \%)$ & \\
\hline $\begin{array}{l}\text { Intellectual } \\
\text { disability }\end{array}$ & $\begin{array}{l}\text { Slight } \\
\text { moderate } \\
\text { severe }\end{array}$ & $\begin{array}{l}4(13.3 \%) \\
14(46.7 \%) \\
10(40.0 \%)\end{array}$ & & \\
\hline \multirow[t]{2}{*}{ Caries } & Yes: n (\%) & $11(36.7 \%)$ & $7(31.8 \%)$ & 0.717 \\
\hline & No: n (\%) & $19(63.3 \%)$ & $15(68.2 \%)$ & \\
\hline \multirow[t]{2}{*}{ Oral lesions } & Yes: n (\%) & $1(3.4 \%)$ & 0 & 0.387 \\
\hline & No: n (\%) & $29(96.6 \%)$ & 0 & \\
\hline \multirow[t]{2}{*}{$\begin{array}{l}\text { Soft deposits on } \\
\text { dental surfaces }\end{array}$} & Yes & $9(30 \%)$ & $10(45 \%)$ & 0.253 \\
\hline & No & $21(70 \%)$ & $12(55 \%)$ & \\
\hline \multirow[t]{2}{*}{$\begin{array}{l}\text { Hard deposits on } \\
\text { dental surfaces }\end{array}$} & Yes & $4(13.3 \%)$ & $10(45 \%)$ & 0.010 \\
\hline & No & $26(86.7 \%)$ & $12(55 \%)$ & \\
\hline
\end{tabular}

Table 2. Analysis of trace elements present in saliva Mean and standard deviation (SD), and $\mathrm{p}$ value

\begin{tabular}{|c|c|c|c|}
\hline Element & $\begin{array}{l}\text { Group study Mean } \\
\quad \pm \text { SD }(\mathbf{N}=30)\end{array}$ & $\begin{array}{c}\text { Control Mean } \pm \text { SD } \\
(\mathbf{N}=\mathbf{2 2})\end{array}$ & \\
\hline $\mathrm{Ca}(\mathrm{g} / 100 \mathrm{gr})$ & $0.0092 \pm 0.0133$ & $0.0079 \pm 0.0024$ & 0.501 \\
\hline $\mathrm{Cr}(\mathrm{mg} / \mathrm{kg})$ & $1.309 \pm 3.8494$ & $0.0360 \pm 0.1684$ & 0.128 \\
\hline $\mathrm{Cu}(\mathrm{mg} / \mathrm{kg})$ & $0.0932 \pm 0.1286$ & $0.1114 \pm 0.4407$ & 0.831 \\
\hline $\mathrm{Fe}(\mathrm{mg} / \mathrm{kg})$ & $4.6626 \pm 9.0565$ & $0.0387 \pm 0.1811$ & 0.009 \\
\hline K (g/100gr) & $0.0698 \pm 0.03001$ & $0.0715 \pm 0.01441$ & 0.795 \\
\hline Mg (g/100gr) & $0.0002 \pm 0.0004$ & $0.0004 \pm 0.0002$ & 0.160 \\
\hline Mn (mg/kg) & $0.0610 \pm 0.0957$ & $0.0005 \pm 0.0021$ & $<0.01$ \\
\hline $\mathrm{Na}$ (g/100gr) & $0.0272 \pm 0.0307$ & $0.0175 \pm 0.0153$ & 0.139 \\
\hline $\mathrm{Ni}(\mathrm{mg} / \mathbf{k g})$ & $0.3978 \pm 0.8731$ & $0.0866 \pm 0.1809$ & 0.107 \\
\hline $\mathrm{Pb}(\mathrm{mg} / \mathrm{kg})$ & $0.1933 \pm 0.3286$ & $0.1597 \pm 0.1687$ & 0.664 \\
\hline$P$ (g/100gr) & $0.0169 \pm 0.0073$ & $0.0178 \pm 0.0061$ & 0.662 \\
\hline Rb (mg/kg) & $0.8031 \pm 1.1977$ & $0.3921 \pm 0.1556$ & 0.1171 \\
\hline$S$ (g/100gr) & $0.0044 \pm 0.0034$ & $0.0046 \pm 0.0024$ & 0.822 \\
\hline Zn (mg/kg) & $3.3857 \pm 9.9561$ & $1.7242 \pm 4.6543$ & 0.472 \\
\hline
\end{tabular}


Table 3. Analysis of trace elements present in unstimulated saliva with caries and soft deposits on dental surfaces

\begin{tabular}{|c|c|c|c|c|c|c|}
\hline \multicolumn{4}{|c|}{ Group With Caries } & \multicolumn{3}{|c|}{ Soft Deposits On Dental Surfaces } \\
\hline Element & STUDY $(\mathbf{N}=11)$ & Control $(N=7)$ & Pvalue & Study $(\mathrm{N}=9)$ & Control $(\mathrm{N}=10)$ & P value \\
\hline $\mathrm{Ca}(\mathrm{g} / 100 \mathrm{gr})$ & $0.008 \pm 0.006$ & $0.008 \pm 0.003$ & 0.888 & $0.007 \pm 0.003$ & $0.008 \pm 0.003$ & 0.661 \\
\hline $\mathrm{Cu}(\mathrm{mg} / \mathrm{kg})$ & $0.068 \pm 0.092$ & $0.305 \pm 0.782$ & 0.326 & $0.046 \pm 0.063$ & $0.221 \pm 0.653$ & 0.438 \\
\hline $\mathrm{Cr}(\mathrm{mg} / \mathrm{kg})$ & $2.510 \pm 6.294$ & $0.112 \pm 0.298$ & 0.334 & $0.480 \pm 0.525$ & $0.079 \pm 0.249$ & 0.045 \\
\hline $\mathrm{Fe}(\mathrm{mg} / \mathrm{kg})$ & $6.829 \pm 13.293$ & $0.121 \pm 0.321$ & 0.205 & $0.934 \pm 1.392$ & $0.085 \pm 0.268$ & 0.075 \\
\hline $\mathrm{K}(\mathrm{g} / 100 \mathrm{gr})$ & $0.066 \pm 0.037$ & $0.069 \pm 0.0161$ & 0.844 & $0.066 \pm 0.020$ & $0.072 \pm 0.014$ & 0.442 \\
\hline $\operatorname{Mg}(g / 100 g r)$ & $0.0001 \pm 0.0003$ & $0.0001 \pm 0.0003$ & 0.065 & $0.0002 \pm 0.0004$ & $0.0005 \pm 0.0002$ & 0.111 \\
\hline $\mathrm{Mn}(\mathrm{mg} / \mathrm{kg})$ & $0.0313 \pm 0.0697$ & $0.001 \pm 0.003$ & 0.280 & $0.036 \pm 0.073$ & $0.001 \pm 0.003$ & 0.142 \\
\hline $\mathrm{Na}(\mathrm{g} / 100 \mathrm{gr})$ & $0.027 \pm 0.034$ & $0.021 \pm 0.025$ & 0.743 & $0.017 \pm 0.008$ & $0.022 \pm 0.021$ & 0.461 \\
\hline $\mathrm{Ni}(\mathrm{mg} / \mathrm{kg})$ & $0.583 \pm 1.389$ & $0.133 \pm 0.303$ & 0.416 & $0.143 \pm 0.079$ & $0.121 \pm 0.250$ & 0.805 \\
\hline $\mathrm{Pb}(\mathrm{mg} / \mathrm{kg})$ & $0.125 \pm 0.174$ & $0.192 \pm 0.249$ & 0.511 & $0.069 \pm 0.071$ & $0.226 \pm 0.207$ & 0.045 \\
\hline $\mathrm{P}(\mathrm{g} / 100 \mathrm{gr})$ & $0.018 \pm 0.007$ & $0.017 \pm 0.006$ & 0.778 & $0.015 \pm 0.007$ & $0.017 \pm 0.006$ & 0.565 \\
\hline $\mathrm{Rb}(\mathrm{mg} / \mathrm{kg})$ & $1.108 \pm 1.859$ & $0.346 \pm 0.185$ & 0.301 & $0.457 \pm 0.124$ & $0.351 \pm 0.131$ & 0.092 \\
\hline $\mathrm{S}(\mathrm{g} / 100 \mathrm{gr})$ & $0.004 \pm 0.001$ & $0.004 \pm 0.002$ & 0.747 & $0.004 \pm 0.002$ & $0.005 \pm 0.002$ & 0.311 \\
\hline $\mathrm{Zn}(\mathrm{mg} / \mathrm{kg})$ & $5.808 \pm 15.948$ & $3.370 \pm 7.799$ & 0.713 & $1.032 \pm 1.104$ & $2.571 \pm 6.496$ & 0.494 \\
\hline
\end{tabular}

Among subjects with caries, mean values of trace elements $\mathrm{Ca}$, $\mathrm{K}, \mathrm{Mg}, \mathrm{Na}, \mathrm{P}$ and $\mathrm{S}$ were very similar, while $\mathrm{Cr}, \mathrm{Fe}, \mathrm{Mn}, \mathrm{Ni}, \mathrm{Rb}$ and $\mathrm{Zn}$ levels were much higher in the study group, while and $\mathrm{Cu}$ and $\mathrm{Pb}$ were higher in the control group, although no element showed statistically significant difference $(p>0.05)$ between the two groups (Table 3). Analyzing subjects showing presence of soft deposits on dental surfaces, $\mathrm{Cr}, \mathrm{Fe}, \mathrm{Mn}$ obtained higher values in the study group, with statistically significant differences for $\mathrm{Cr}(\mathrm{p}=0.045)$ and $\mathrm{Pb}(\mathrm{p}$ $=0.045$ ) (Table3). For subjects showing presence of hard deposits, $\mathrm{Cr}$, $\mathrm{Fe}, \mathrm{Mn}, \mathrm{Ni}$ and $\mathrm{Rb}$ obtained higher mean values in the study group, while $\mathrm{Ca}, \mathrm{Cu}, \mathrm{Na}, \mathrm{Pb}$ and $\mathrm{Zn}$ were higher in the control group, although statistically significant differences were not found between study and control subjects.

\section{Discussion}

Healthcare for patients with intellectual disabilities is of increasing interest to healthcare professionals as many of these patients have a limited capacity for cooperation, communication, and oral self-care and so constitute a risk group requiring specialized dental care from an early age $[5,6]$.

Lakshmi and Geetha [17] studied the levels of certain trace elements in the hair and nails of children with autism, finding higher concentrations of $\mathrm{Cu}, \mathrm{Pb}$ and $\mathrm{Hg}$ than among healthy children, as well as decreased levels of $\mathrm{Mg}, \mathrm{Zn}$ and Se. It is known that the presence of $\mathrm{Cu}$ is essential to health but excessive levels have neurotoxic effects such as irritability, depression, nervousness and learning and behavioral disorders. Kalra, et al. [18] found lower blood levels of $\mathrm{Fe}, \mathrm{Cu}$ and $\mathrm{Mg}$ among children with cerebral paralysis compared with a group of healthy children. In the present study, mean Fe and $\mathrm{Mn}$ values were significantly higher in subjects with intellectual disability than control subjects. Manganese $(\mathrm{Mn})$ is an essential nutrient that protects against oxidative damage; but exposure to excessive levels of Mn can cause toxic effects, especially on the central nervous system; neurotoxic effects have been detected in children exposed to high concentrations of $\mathrm{Mn}$ in drinking water. Neurotoxicity deriving from Mn produces subtle early effects that may be present prior to the appearance of any clinical signs or symptoms $[18,19]$.

The main oral health problems among children with intellectual disabilities are dental caries, periodontal disease, and malocclusion [5-8]. Among the various factors involved in the appearance of these diseases are poor oral hygiene maintenance, a cariogenic diet, oral respiration, bruxism and thumb sucking. A cariogenic diet is common among all children, as many eat between meals, often in the form of refined carbohydrates and it is difficult to manage or prevent this behavior [3-5]. They are also affected by the medications manufactured for children with high sugar content, which have secondary effects such as gingival hyperplasia or increased risk of caries. The present study did not find significant differences in oral health status between the study and control groups.

Poor oral hygiene is common among persons with intellectual disability who often suffer high levels of dental plaque, gingivitis, intense halitosis with food remnants left on the teeth and mucosa [20]. Gingival inflammation can develop extensively and rapidly at an early age among children with intellectual disability, more so than among children without this disability, increasing in severity with age and according to the degree of disability [14,21]. In the present work, $30 \%$ of the subjects with intellectual disability presented bacterial plaque, a similar percentage to the control group. Perhaps this can be explained by the fact that this particular group was under the supervision of a multidisciplinary group of healthcare professionals.

Concentrations of oligoelements in saliva have been associated with the incidence of oral disease in different population groups [14]. In this context, determining the concentrations of trace elements is important for a better understanding of their impact on oral health. In subjects presenting good oral health, mean $\mathrm{Ca}, \mathrm{Cu}, \mathrm{Cr}, \mathrm{Fe}, \mathrm{Na}, \mathrm{Mn}$, $\mathrm{Ni}, \mathrm{Pb}, \mathrm{Rb}$ and $\mathrm{Zn}$ concentrations were higher in the study group, with statistically significant differences for $\mathrm{Cu}, \mathrm{Fe}, \mathrm{Mn}$ and $\mathrm{Na}(\mathrm{p}<0,05)$. Disequilibrium in Fe levels affects the periodontal, bone metabolism, and host response, Fe being essential to life as it plays a role in almost all oxidation/reduction (redox) processes and is present in many enzymes involved in the maintenance of cell integrity [14].

When the trace elements present in subjects with caries in both groups were analyzed, it was found that mean $\mathrm{Cr}, \mathrm{Fe}, \mathrm{Mn}, \mathrm{Ni}, \mathrm{Rb}$ and $\mathrm{Zn}$ levels were higher in the study group. Increased $\mathrm{Cu}$ and $\mathrm{Pb}$ could be related to dental caries, as stated by Zhair, et al. [22]. Although the mechanism of interrelation between $\mathrm{Cu}$ in saliva and caries remains unknown, a possible explanation is that the fracture of hydroxyapatite crystals releases $\mathrm{Cu}$ ions into saliva [12]. Decreases in other trace elements such as $\mathrm{Ca}$ and $\mathrm{Zn}$ have been associated with caries and would appear to play a protective role, whereby increasing amounts of these trace elements in diet could improve oral and dental health status. However, Bhandary, et al. [23] obtained contradictory results, 
with lower levels of $\mathrm{Cu}$ and $\mathrm{Zn}$ in patients with caries. Zinc ( $\mathrm{Zn})$ is naturally present in plaque, saliva and teeth and is essential to the remineralization process, while its deficit increases the frequency of infection and degenerative pathology.

The saliva collection procedure is easy, inexpensive, and noninvasive. Furthermore, the samples are readily accessible (24). The study suffered several limitations, in particular its small sample size and transversal design. Further research is necessary through studies of prospective design. Furthermore, gingival inflammation was measured using the simplified version of the Greene and Vermillion oral hygiene index (GVOHI-S); as an oral hygiene index, this is not the appropriate means of measuring periodontal disease activity. However, the index could be a significant parameter for oral health analysis and in particular for assessing the oral health of persons with disability.

In conclusion, both the group of subjects with intellectual disability and the control group presented similar oral healthcare needs. Concentrations of $\mathrm{Ca}, \mathrm{K}, \mathrm{Mg}, \mathrm{Na}, \mathrm{Pb}, \mathrm{P}$ and $\mathrm{S}$ in saliva were similar in both groups. But mean $\mathrm{Fe}$ and $\mathrm{Mn}$ values were significantly higher among subjects with intellectual disability and control subjects. This poses the question of whether these differences could be a reflection of intellectual disability.

\section{Conflict of interest}

The authors declare that they have no conflict of interest.

\section{References}

1. De Jongh A, Van Houtem C, Van Der Schoof M, Resida G, Broers D (2008) Oral health status, treatment needs, and obstacles to dental care among noninstitutionalized children with severe mental disabilities in the Netherlands. Spec Care Dent 28: 111-115. [Crossref]

2. Solanki J, Gupta S, Arya A (2014) Dental caries and periodontal status of mentally handicapped institutilized children. J Clin Diagn Res 8: ZC25-7. [Crossref]

3. Escribano A, Hernández T, Ruiz E, Porteros JA (2007) Results of a dental care protocol for mentally handicapped patients set in a primary health care area in Spain. Med Oral Patol Oral Cir Bucal 12: 492-495. [Crossref]

4. Chandna P, Adlakha VK, Joshi JL (2011) Oral status of a group of cerebral palsy children. $J$ Dent 3: 18-21.

5. Zhou N, Wong HM, Wen YF, Mcgrath C (2017) Oral health status of children and adolescents with intellectual disabilities: a systematic review and meta-analysis. Dev Med Child Neurol 59: 1019-1026. [Crossref]

6. Oliveira JS, Prado Junior RR, de Sousa Lima KR, de Oliveira Amaral H, Moita Neto JM, et al. (2013) Intellectual disability and impact on oral health: a paired study. Spec Care Dentist 33: 262-268. [Crossref]

7. Moreira RN, Alcantara CEP, Mota-Veloso I, Marinho SA, Ramos-Jorge ML, et al. (2012) Does intellectual disability affect the development of dental caries in patients with cerebral palsy? Res Dev Disabil 33: 1503-1515. [Crossref]
8. Bhattacharya PT, Misra SR, Hussain M (2016) Nutritional Aspects of Essential Trace Elements in Oral Health and Disease: An Extensive Review. Scientifica (Cairo) 2016 : 1-12. [Crossref]

9. Grădinaru I, Ghiciuc CM, Popescu E, Nechifor C, Mândreci I, et al. (2007) Blood plasma and saliva levels of magnesium and other bivalent cations in patients with parotid gland tumors. Magnes Res 20: 254-258. [Crossref]

10. Duggal MS, Chawla HS, Curzon ME (1991) A study of the relationship between trace elements in saliva and dental caries in children. Arch Oral Biol 36: 881-884. [Crossref]

11. Hegde MN, Hegde ND, Ashok A, Shetty S (2014) Biochemical indicators of dental caries in Saliva: An in vivo study. Caries Res 48: 170-173. [Crossref]

12. Watanabe K, Tanaka T, Shigemi T, Hayashida Y, Maki K (2009) Mn and $\mathrm{Cu}$ concentrations in mixed saliva of elementary school children in relation to sex, age, and dental caries. J Trace Elem Med Biol 23: 93-99. [Crossref]

13. Borella P, Fantuzzi G, Aggazzotti G (1994) Trace elements in saliva and dental caries in young adults. Sci Total Environ 153: 219-224. [Crossref]

14. Gaur S, Agnihotri R (2017) Trace Mineral Micronutrients and Chronic Periodontitis-a Review. Biol Trace Elem Res 176: 225-238. [Crossref]

15. Alghadir AH, Gabr SA, Al-Eisa E (2016) Effects of Physical Activity on Trace Elements and Depression Related Biomarkers in Children and Adolescents. Biol Trace Elem Res 172: 299-306. [Crossref]

16. Puy CL (2006) La saliva en el mantenimiento de la salud oral y como ayuda en el diagnóstico de algunas patologías. Med Oral Patol Oral Cir Bucal 11: E449-455. [Crossref]

17. Lakshmi Priya MD, Geetha A (2011) Level of trace elements (copper, zinc, magnesium and selenium) and toxic elements (lead and mercury) in the hair and nail of children with autism. Biol Trace Elem Res 142: 148-158. [Crossref]

18. Kalra S, Aggarwal A, Chillar N, Faridi MMA (2015) Comparison of Micronutrient Levels in Children with Cerebral Palsy and Neurologically Normal Controls. Indian J Pediatr 82: 140-144. [Crossref]

19. Khalique A, Shah MH, Jaffar M, Shaheen N, Tariq SR, et al. (2006) Multivariate analysis of the selected metals in the hair of cerebral palsy patients versus controls. Biol Trace Elem Res 111: 11-22. [Crossref]

20. Bakry NS, Alaki SM (2012) Risk factors associated with caries experience in children and adolescents with intellectual disabilities. $J$ Clin Pediatr Dent 36: 319-324. [Crossref]

21. Petrovic BB, Peric TO, Markovic DLJ, Bajkin BB, Petrovic D, et al. (2016) Unmet ora health needs among persons with intellectual disability. Res Dev Disabil 59: 370-377. [Crossref]

22. Zahir S, Sarkar S (2006) Study of trace elements in mixed saliva of caries free and caries active children. J Indian Soc Pedod Prev Dent 24: 27-29. [Crossref]

23. Bhandary S, Shetty A, Hegde MN (2015) Correlation of trace elements in saliva with dental caries activity. Int J Curr Res 7: 18574-18577

24. Michalke B, Rossbach B, Gaen T, Schaferhenrich A, Scherer G (2015) Saliva as a matrix for human biomonitoring in occupational and environmental medicine. Int Arch Occup Environ Health 88: 1-44. [Crossref]

Copyright: (C2019 Antonio RRJ. This is an open-access article distributed under the terms of the Creative Commons Attribution License, which permits unrestricted use, distribution, and reproduction in any medium, provided the original author and source are credited. 